\title{
Peer Tutor Learning Model in CRE-Based Discipleship Teaching According to Matthew 28:19-20 at High Schools in Makassar City
}

\author{
Sarce Rien Hana ${ }^{1)^{*}}$ Ivan Th. J. Weismann ${ }^{2)}$ \\ 1) Sekolah Tinggi Filsafat Theologia Jaffray Makassar, Indonesia \\ 2) Sekolah Tinggi Filsafat Theologia Jaffray Makassar, Indonesia \\ ${ }^{*}$ Correspondent author: sarcehanal23@gmail.com
}

Received: 03 February 2020/Revised: 10 March 2020/Accepted: 20 March 2020

\begin{abstract}
This scientific work digs deeper into the peer tutoring learning model to be applied to Christian Religious Education (CRE) teaching in high schools. The peer tutoring learning model contained the following steps. First, choose the material and divide it into sub-materials. Second, the teacher forms heterogeneous groups of students as many sub-materials. Third, each group learns the material guided by intelligent students. Fourth, allow sufficient time for preparation both inside and outside the classroom. Fifth, each group, through their representatives, submits sub-materials following the given tasks. The teacher remains as a resource. Sixth, provide conclusions and clarifications if there is a student understanding that needs to be straightened. Besides, the problem of achieving CRE goals for students, as well as the material presented in curriculum learning, touches on Matthew 28:19-20's mandate. The formulation of the problem studied is "How is the concept of discipleship, according to Matthew 28:19-20 applied to the teaching of CRE in high schools using the peer tutoring learning model?" The aim to be achieved in this research is to formulate disciplinary formulas and materials, and according to Matthew 28:19-20 to be applied by using the model of peer tutoring in teaching CRE at High School in Makassar City. The method used in this study is a research and development method or in English called research and development abbreviated as R\&D. The main conclusion reached is CRE-based discipleship teaching according to the Gospel of Matthew 28:19-20 in line with the Great Commission, thereby increasing the chances of the commission being carried out.
\end{abstract}

Keywords: education, learning model, tutor, Great Commission, discipleship

\section{Abstrak}

Tulisan ilmiah ini menjelaskan lebih dalam model pembelajaran tutor sebaya untuk diterapkan pada pengajaran Pendidikan Agama Kristen (PAK) di sekolah menengah. Selain itu, masalah pencapaian tujuan CRE untuk siswa, serta materi yang disajikan dalam pembelajaran kurikulum menyentuh pada 
Amanat Agung dalam Injil Matius 28: 19-20. Rumusan masalah yang diteliti adalah "Bagaimana konsep pemuridan menurut Matius 28: 19-20 diterapkan pada pengajaran CRE di sekolah-sekolah tinggi menggunakan model pembelajaran tutor sebaya?" Metode yang digunakan dalam penelitian ini adalah metode penelitian dan pengembangan disingkat dengan metode R\&D. Hipotesis dalam penelitian ini adalah sebagai berikut: Siswa yang diberikan materi pengajaran PAK sama dengan materi pengajaran Yesus berdasarkan Matius 28: 19-20 menggunakan model pembelajaran Peer Tutor yang mengalami perjumpaan dengan Tuhan Yesus. Siswa kemudian menggunakan bahan yang diajarkan kepadanya untuk memuridkan siswa lain, dan seterusnya sampai semua bangsa menjadi murid-Nya. Kesimpulan utama yang dicapai adalah pengajaran PAK berbasis pemuridan sesuai dengan Injil Matius 28: 1920 sejalan dengan Amanat Agung, dengan demikian meningkatkan pelaksanaan Amanat Agung.

Kata-kata Kunci: Pendidikan, model pembelajaran, tutor, Amanat Agung, pemuridan

\section{Introduction}

The pattern of Jesus' teaching was not only practiced in the churches but also in schools from elementary school through college. The lesson is known as Christian Religious Education or is abbreviated as CRE. CRE is one of the subjects in the educational curriculum of the Republic of Indonesia. In Education (Law) Education No. 20 In 2003, section 37 paragraph la listed Religious Education as one of the subjects taught in the Indonesian education curriculum. Under the same law, Article 30, verse 1 is held following the religion. Article 30 of paragraph 1 reads: "Religious Education Article 30 (1) Religious education is conducted by the Government and community groups of religious converts, following the laws." "'

For Karen Tye, "A Foundational building block in the educational ministry of the church." According to Kenneth D. Gangel, Christian Education "is the teaching-learning order to fulfill Christ's mandate to make a disciple." 3 He said that Christian Education is focused on

\footnotetext{
${ }^{1}$ Law No. 20 Tahun 2003 Pasal 30," accessed July 3 $3^{\text {rd }}, 2018$, http://kelembagaan.ristekdikti.go.id/wpcontent/uploads/2016/08/UU_no_20_th_2003.pdf.

${ }^{2}$ Karen Tye, Basics of Christian Education (USA: Chalice Press, 2000), 18.

${ }^{3}$ Kenneth D. Gangel, The Teaching-Learning Process in Christian Education in Robert E. Clark, Lin Johnson, and Allyn K. Sloat, Christian Education: Foundations for the Future (USA: Moody Publishers, 1991).
} 
teaching the Word of God. ${ }^{4}$ Sidjabat also revealed that Christian Education is a tool to instill Christian values. ${ }^{5}$ This is also in line with Nuhamara, who stated straightforwardly that Christian Education became a means - a thing close to - character education. ${ }^{6}$ Based on some of the points above, Christian Education is foundational of church ministry, and it's a teaching-learning order to fulfill the mandate of Christ, and it's the focus in the Word of God. Christian Education can be a tool to instill Christian values and build character.

Thus, CRE is not merely a learning process, but also, there are goals to be achieved in the learning process. According to Catechesi Tradendae (1979), religious education aims to develop initial faith and advance it in fullness. Religious Education will help even young and old to grow day by day. ${ }^{7}$ The other purpose of Religious or Christian Education is to bring someone to Father through the encounter with Jesus The Son. ${ }^{8}$ So, it means that this education is focusing on bringing someone to Jesus; it's Christo-Centric. Thomas Groome, the purpose of Christian education, is: "to enable people to live as Christians, that is, to live lives of Christian faith." From the experts' presentation, it is clear that CRE is the focus to bring someone to Jesus Christ and lead and enable people to live the Christian life, in the fullness of faith and nourish it day by day.

Government Regulation No. 55/2007 concerning religious education stated that religious education functions to form Indonesian people who believe in and fear God Almighty and have good character and are able to maintain peace and harmony in inter and interfaith religious relations (Article 2 paragraph 1). Furthermore, it is mentioned that religious education aims to develop students' abilities in understanding, to live, and practicing ethical values that harmonize their

${ }^{4}$ Ibid.

${ }^{5}$ Binsen Samuel Sidjabat, "Kerangka Kurikulum Pendidikan Agama Kristen Berbasis Karakter di Perguruan Tinggi," Jurnal Jaffray 17, no. 1 (April 5, 2019): 74, accessed December 12 ${ }^{\text {th }}, 2019$, https://doi.org/10.25278/jj7l.vl7il.314.

${ }^{6}$ Daniel Nuhamara, "Pengutamaan Dimensi Karakter Dalam Pendidikan Agama Kristen," Jurnal Jaffray 16, no. 1 (March 19, 2018): 93, https://doi.org/10.25278/jj7l.vl6il.278.

${ }^{7}$ Carlos C. Roberts, Christian Education Teaching Methods - from Modern to Postmodern: Teaching the Faith to Post-Moderns (Bloomington: AuthorHouse, 2009), 33.

${ }^{8}$ Ibid., 34.

${ }^{9}$ Thomas Groome in Tye, Basics of Christian Education, 22. 
mastery in science, technology, and art (Article 2 paragraph 2). ${ }^{10}$ So both the experts and the government of the Republic of Indonesia, all agreed, that CRE fills not only the cognitive realm. But it also affective and psychomotor students in the form of practice of what they learn.

To implement the mandate of the Education Law so that it is evenly distributed throughout Indonesia, a curriculum is compiled that must be used by every unit and level of education throughout Indonesia. Since Indonesia's independence in 1945, the education curriculum has changed 11 times. The first curriculum is in 1947, then 1947, 1952, 1964, 1968, 1975, 1984, 1994, 2004, 2006, 2013, and 2015. Each curriculum has its characteristics tailored to government policy at that time.

Makassar City, as one of the major cities in Indonesia, always tries to follow the education guidelines set by the central government. All high schools are required to use the curriculum set by the government, in this case, the Ministry of National Education of the Republic of Indonesia, namely the 2013 curriculum, but until the 2018/2019 academic year, there are still schools that have not fully used this curriculum. There are always high schools whose class XII is again using the Education Unit Level Curriculum. This is reflected in the statement of Simon Rumante, Chairperson of the Makassar CRE Subject Teachers Association, "National-Based School Exams for the 2018/2019 academic year for CRE subjects using questions based on the Education Unit Level Curriculum and 2013's Curriculum (K-13) because there are still schools with class XII using the Education Unit Level Curriculum."

A curriculum that has been painstakingly determined by the government is undoubtedly intended so that education in Indonesia has clear guidelines and directions. Unfortunately, since the beginning of the curriculum compilation, it is closely related to government policy. So that the subjects taught from first grade to third grade of High School, do not touch the core of CRE itself, namely meeting with Christ and practicing his faith in daily life as already previously disclosed. The subject matter contained in the Education Unit Level Curriculum discusses the world of adolescents who grow into adulthood, the holy

10“PP No. 55 Tahun 2007," http://kelembagaan.ristekdikti.go.id/wpcontent/uploads/2016/08/PP_55_2007-Pendidikan-Agama-Keagamaan.pdf.

11 Simon Rumante, The Leader of Teacher's Deliberation Subjects in Christian Religious Education in Makassar City, Interview by the Author, Makassar, January $25^{\text {th }}, 2019$. 
spirit, the family church, the surrounding environment, and human rights. Whereas for 2013's Curriculum (K-13), the material presented is less, first grade was taught about growing into adulthood, second grade was taught about family, and third grade was taught about Human Rights. ${ }^{12}$

The absence of a clear road map on the direction of national education has an impact on CRE, especially in high schools. George Knight, in his book Philosophy and Education, writes, "Perhaps the greatest need of Christian schools is a philosophical foundation that is truly Christian."13 The greatest need for Christian schools is the basis of genuinely Christian philosophy. Judith Teeter, "The theme of my philosophy is God all, in all, to all which is based on 1 Corinthians 15:28 and Mark 16:15."14

Christian Religious Education is a subject that emphasizes character education and character, requires an attractive learning model for students. CRE needs a model that is able to motivate students to speak and express their opinions. Besides, they can have a cooperative relationship between one student and another. This idea will be great for encouraging students to have the ability to witness to others about God's actions in him.

There are quite a lot of learning models, including peer teaching models. M. Muthma'innah said that peer tutor learning puts students to learn in a group. They try to work together, depend on teamwork. So instead of depending on the teacher's explanation, students can learn from their peers. Through this model of learning, "student is not served as the object of a lesson, but become the subject of learning." 15 The peer tutor learning model is an alternative that can be applied to students in teaching and learning.

${ }^{12}$ Ministry of Education and Culture Republic of Indonesia, Pendidikan Agama Kristen dan Budi Pekerti SMA/SMK Kelas X, XII, dan XII (Jakarta: Kementerian Pendidikan dan Kebudayaan, 2015).

${ }^{13}$ George R. Knight, Philosophy and Education: an Introduction in Christian Perspective (Berrien Springs, MI, USA: Andrews University Press, 1998), 157.

${ }^{14}$ Judith Teeter, "Philosophy of Ministries," Jurnal Simpson 1, No. 1 (2014):2, https://journal.sttsimpson.ac.id/index.php/Js/article/view/10/9.

${ }^{15}$ M. Muthma'innah, "What's about Peer Tutoring Learning Model?" Journal of Physics: Conference Series 895 (September 2017): 1-2, https://doi.org/10.1088/17426596/895/1/012064. 
The peer tutoring learning model, according to Saminanto contained the following steps. First, choose the material and divide it into sub-materials. The choice of material is certainly adjusted to the subject matter, as included in the lesson plan. Second, the teacher forms heterogeneous groups of students as many sub-materials. Smart students are spread out in each group and act as peer tutors. Third, each group learns the material guided by intelligent students. Fourth, allow sufficient time for preparation both inside and outside the classroom. Fifth, each group, through their representatives, submits sub-materials in accordance with the given tasks. The teacher remains as a resource. Sixth, provide conclusions and clarifications if there is a student understanding that needs to be straightened. ${ }^{16}$

The use of peer tutoring learning models can train students or can improve the ability to express opinions and communicate. These skills relate to the strength of students to capture the understanding or meaning of what is heard, read, and seen or done, then explain research or the purpose of catches and the results of mind processing with their language or words so that others understand them. Besides, peer tutoring learning can train students' ability to take the initiative and be creative in doing new things or other things in dealing with a problem. Students are also trained to work together with others. They compact hin handling an activity that is designed with the teacher to get the maximum benefit. In the learning process, the teacher continues to supervise and assist peer tutors in classroom learning.

It can be seen that peer tutoring learning is very beneficial for learners. Thus, this will be very useful if practiced in Christian Religious Education. In this article, the author tries to use a tutor-based learning model with discipleship. Cox Jr. and Peck said that Christian Religious Education should focus on discipleship. This is due to him the formation of discipleship is the settlement of eternal transcendence issues of life. ${ }^{17}$

\footnotetext{
${ }^{16}$ Saminanto, PTK (Semarang: RaSAIL Media Group, 2010), 48; Each model has steps (syntax) like the STAD learning model (See Hengki Wijaya and Arismunandar Arismunandar, "Pengembangan Model Pembelajaran Kooperatif Tipe STAD Berbasis Media Sosial," Jurnal Jaffray 16, no. 2 (October 6, 2018): 175-96, https://doi.org/10.25278/jj7l.vl6i2.302.

${ }^{17}$ William Cox and Robert Peck, "Christian Education as Discipleship Formation," Christian Education Journal: Research on Educational Ministry 15, no. 2 (June 7, 2018): 243, https://doi.org/10.1177/0739891318778859; (see Peniel C. D. Maiaweng, "Ulasan Buku: Spiritual Formation: Menjadi Serupa dengan Kristus," Jurnal Jaffray 13, no.
} 
Based on the background study of the problem above, this research attempts to answer the main question, namely: "How is the concept of discipleship according to Matthew 28: 19-20 applied to teach CRE in high schools using peer tutoring learning models?" The objectives to be achieved in This research are formulating the formulation and discipleship material and, according to Matthew 28: 19-20, to be applied using peer tutoring learning models in teaching CRE in high schools in Makassar City. By not trying to rule out other sentences, and reducing the meaning and purpose of the Great Commission. This research is limited to the sense of the Great Commission specifically on the phrase "make all nations my students" and its relation to CRE learning using peer tutoring methods in high schools throughout the Makassar City.

\section{Theory}

\section{Peer Tutor Learning Model}

Villa, Thousand, and Nevin describe Peer Tutor Learning as a process performed by a student with reasonable competence in their field, helping other students who are of the peers or have the same skills or levels or concepts. Of course, under the supervision of his teacher. ${ }^{18} \mathrm{E}$. Gordon said, Peer Tutor Learning is an instructional method using one child as a "teacher" to tutors another. He tutors in materials that he already expert. Sometimes peer tutor substituted for cross-age tutoring older student teaches the younger. ${ }^{19}$ Gordon said that there are many other descriptive terms for peer tutoring: "peer teaching," "partner learning," "peer education," "child-teach-child," "mutual instruction." ${ }^{20}$ As a conclusion, Peer Tutor Learning is a method that performed by a student that expert in

l (March 28, 2015): 141-43, https://doi.org/10.25278/jj7l.vl3il.119); Herwinesastra Herwinesastra, "Pengaruh Model Mentoring Robert Clinton Terhadap Kecakapan Kepemimpinan Pekerja di GKII Daerah Pontianak," Jurnal Jaffray 17, no. 2 (October 1l, 2019): 259-79, https://doi.org/10.25278/jj.vl7i2.365; Agus Prihanto, "Peran Proses Mentoring Pemimpin Kaum Muda Bagi Perkembangan Pelayanan Pemuda Di Gereja," Jurnal Jaffray 16, no. 2 (October 6, 2018): 197-212, https://doi.org/10.25278/jj7l.vl6i2.258.

${ }^{18}$ Richard A. Villa, Jacqueline S. Thousand, and Ann I. Nevin, Collaborating With Students in Instruction and Decision Making: The Untapped Resource (USA: Corwin Press, 2010), 62-63.

${ }^{19}$ Edward E. Gordon, Peer Tutoring: A Teacher's Resource Guide (Maryland: R\&L Education, 2005), 1.

${ }^{20} \mathrm{Ibid}$. 
some materials and then teaches another student that have weakness in those materials, under their teacher's guidance.

Gordon adds that there are some strategies for a peer tutoring program. ${ }^{21}$ First, defining and planning tutoring program. Second, we train student peer tutor methods. Make sure that they're ready to teach. Third, monitoring the result of the learning program. Formal and informal assessment tools can be used to see the result of the tutoring program. Forth, finding support from different groups: the school's principal, the students, and the student's parents. Five, sustaining the peer tutor program.

\section{Discipleship}

The Imitation of Christ

Consider to Bill Hull; the crucial point discipleship is to imitate Christ. ${ }^{22}$ The imitation of Christ doesn't mean we try to become equal with God. Instead, we try to live like Jesus and should affect another as the way he did too. ${ }^{23}$ Hull continued and said that to become Christlikeness, is worth working for. "It's worth all the pain and anguish because it's the only thing that matters. This spiritual formation should be the church's first and exclusive works. So, we should make it our guiding principle and measure every effort of the church and ministry with it. The imitation of Christ provides the scale, and we measure how a ministry spends its money, how it uses its time, how the best and brightest people serve with this scale." ${ }^{24}$ Imitating Christ is worth and should be exclusive in the fellowship of God's people (Colossians 1:2829; Galatians 4:19-20).

\section{The Call to Discipleship 25}

To understand the call to discipleship, Hull uses Luke 9:23-25 as the foundation. He uses some facets of the verses to understand this call. First, there is an urge to follow Jesus. If someone fells an urge to follow Christ, that's mean God is working on that person. Second, the call to discipleship is to lead us to live differently - as Jesus lived - and follow Him by faith. Third, He chose anyone to become His followers, to become his disciples. Forth is self-denial. He calls us to deny ourselves,

${ }^{21}$ Gordon, 2-3.

${ }^{22}$ Bill Hull, The Complete Book of Discipleship: On Being and Making Followers of (Colorado Springs: NavPress, 2014).

${ }^{23}$ Ibid.

${ }^{24}$ Ibid.

${ }^{25}$ Ibid. 
says no to a person to say yes to God, and giving up control to Him. Fifth, know Christian's mission in Christ through our "sweet spot" - the condition where we can be fruitful or show our strength (spiritual gifts). Sixth, ready to live daily in the middle of temptation, weakness, illness, opposition, and the appearance of failure. Seventh, gaining our soul and save our lives with losing it (Luke 9:24).

The Six-Fold Definition Being Conformed to Christ's Image ${ }^{26}$

According to Bill Hull, there are six issues of transformation that include when someone is becoming like Christ. First is the person's mind is transformed. They believe what Jesus believed. Second, is the person's character changed? They live the way Jesus lived. The third is the person's relationships transformed. They love people as Jesus loves His people. Forth is the person's habits are changed. They train to live as Jesus instructed. Fifth, the person's service is transformed. Become a minister like Jesus. Sixth, a person's influence is transformed. They lead the way as Jesus lead.

\section{Peer Tutor Learning Model in Christian Religious Education Based on Discipleship}

From Villa, Thousand, Nevin, ${ }^{27}$ and also Gordon ${ }^{28}$, we knew that Peer Tutor Learning is an instructional method that performed by a student that expert in some materials under their teacher's guidance. In Christian Religious Education, the teacher chose some student to become a tutor for their friends. The teacher wanted some students that have an expert in Christian Education. Also, because it based on discipleship, it means that the teacher also pays attention that these students have the characters of Jesus or they try to live as Jesus lived they love Jesus. ${ }^{29}$ They will help their friend to become Christlikeness. One of the results of this method is students becoming more like Christ, and they encourage to share the love of God through Christ.

${ }^{26}$ Ibid.

${ }^{27}$ Richard A. Villa, Jacqueline S. Thousand, and Ann I. Nevin, Collaborating With Students in Instruction and Decision Making: The Untapped Resource (USA: Corwin Press, 2010), 62-63.

${ }^{28}$ Edward E. Gordon, Peer Tutoring: A Teacher's Resource Guide (Maryland: R\&L Education, 2005), 1.

${ }^{29}$ Hull, The Complete Book of Discipleship. 


\section{Method}

The method used in this research is the research and development method, abbreviated as R\&D. Research and development methods are research methods used to produce specific products and test the effectiveness of these products. ${ }^{30}$ To be able to produce specific products used research that is needs analysis (used survey methods or qualitative) and to test the effectiveness of these products to function on the broader community, research is needed to test the efficacy of these products (used experimental methods). ${ }^{31}$ Borg and Gall have ten stages of R\&D research, namely: (1). Research and information collecting, (2). Planning, (3). Develop a preliminary form of product; (4). Initial field testing, (5). Primary product revision, (6). Main field testing, (7). Operational product revision, (8). Functional field testing, (9). Final product revision, (10). Dissemination and implementation. ${ }^{32}$

The validity of the learning model and tools is carried out by several validators or observers. The criteria set for the validity of the model and learning tools are as follows.

Table 1. Validity levels of learning models and devices

\begin{tabular}{ccc}
\hline Numb. & Score & Criteria \\
\hline 1 & $3,5 \leq X \leq 4,0$ & Very valid \\
2 & $3,0 \leq X \leq 3,49$ & Valid \\
3 & $2,5 \leq X \leq 2,99$ & Valid enough \\
4 & $2 \leq X \leq 2,49$ & Invalid \\
\hline
\end{tabular}

\section{Results and Discussion}

\section{Peer Tutor Learning Model in High Schools in Makassar City}

Samples selected from all schools in Makassar were chosen from schools implementing CRE. The Samples were selected from as many as four schools consisting of 2 state high schools, one state vocational

${ }^{30}$ Sugiyono, Metode Penelitian Pendidikan Pendekatan Kuantitatif, Kualitatif, dan R e D (Bandung: Alfabeta, 2009), 407.

${ }^{31}$ Sri Haryati, "Research And Development (R\&D) Sebagai Salah Satu Model Penelitian Dalam Bidang Pendidikan," Jurnal Dinamika 37, No. 1 (September 2012):11-26.

${ }^{32}$ W. R. Borg and M. D. Gall, Educational Research: An Introduction (New York: Longman, 1983), 775 . 
school, and one private high school run by a Christian foundation. The selection of these schools was not only based on being considered to represent all high schools in Makassar. The school gives the permits and facilities. The CRE teachers who were able to study the subjects in the implementation of this research and development. The total sample selected for students was chosen by five people from each school wherein each school there was a student who was a peer tutor, while the CRE teachers interviewed were four people.

The process of collecting data on teachers is done through structured interviews. At the same time, students are carried out by distributing questionnaires to identify problems and learning. Models used in discipleship in high schools in Makassar so far, as well as the application of peer tutoring learning models in their respective schools, especially on CRE-based discipleship subjects according to Matthew 28: $19-20$.

\section{Description of CRE Teacher Answers}

From the overall answers of the teachers, some conclusions can be drawn as follows. First, the teachers try to carry out their tasks professionally using handbooks following the curriculum set by the Indonesian Ministry of Education. Second, the teachers use the learning model following the circumstances of the students and their habits. Third, the study material contained in the handbook is not in line with the Great Commission in Matthew 28: 19-20, even though it has values that intersect with it. Fourth, the emphasis on teaching materials for high school students contained in the teacher handbook emphasizes more on character according to CRE.

\section{Description of High School Student Answers}

Questionnaires submitted to students were given the emphasis on the learning models used so far, the obstacles encountered, and students' uptake of CRE material taught to them. A questionnaire with ten questions was given three choices of answers.

From the overall answers of the students, some conclusions can be drawn as follows. First, the teaching teacher has worked hard to teach well, using several methods and handbooks following those provided by the Ministry of National Education to maximize the absorption of students. Second, the material given to students is not directed at 
students' conversion and does not touch the Great Commission of Jesus Christ to make disciples of all nations. This is clearly illustrated by the statements of students who did not understand the Great Commission. Third, the model used by teachers has been varied and is quite useful in teaching high school students in Makassar City. Most students can understand the material presented by these methods.

\section{CRE Teaching Design Using Peer Tutor Learning Model}

Discipleship-based teaching of CRE based on the Gospel of Matthew 28: 19-20 uses the peer tutoring learning model. The peer tutoring learning model, according to Saminanto contained six steps. ${ }^{33}$ Based on the steps of the peer tutor learning model, the stages of learning in the control group are divided into 3 phases.

Table 2. Steps of the Peer Tutor Learning Model

\begin{tabular}{|c|c|}
\hline Phase & Information \\
\hline Phase l & 15 minutes regarding the discussion are \\
\hline Teacher & Orientation, Apperception, Motivation and Giving \\
\hline Introduction & Reference \\
\hline Activities & \\
\hline Phase 2 & 105 minutes regarding the discussion are \\
\hline The Core Activity & Stimulation, Problem Statement, Data Collection, Data \\
\hline & Processing, Verification, and Generalization \\
\hline Phase 3 & 15 minutes consists of personal teacher activities \\
\hline The Closing Activity & and teaching activities with students \\
\hline
\end{tabular}

\section{Results of Analysis of Teaching Implementation Plans (CSPs)}

In analyzing the teaching implementation plan (RPP), the things that are assessed are: a) Introduction, b) This activity, c) Closing, d) Ability to manage time, and e) Classroom atmosphere. A summary of the results of the RPP assessment is illustrated in table 3.

Table 3. Assessment of Teaching Implementation Plan.

\begin{tabular}{llllllll}
\hline \multirow{2}{*}{ Numb. } & \multirow{2}{*}{ Aspect } & \multicolumn{5}{c}{ Observer } & \multirow{2}{*}{ Average } \\
\cline { 3 - 7 } & & 1 & 2 & 3 & 4 & 5 & \\
\hline 1 & Introduction & 3,6 & 3,8 & 4,0 & 3,6 & 3,6 & 3,7
\end{tabular}

${ }^{33}$ Saminanto, PTK (Semarang: RaSAIL Media Group, 2010), 48. 


\begin{tabular}{|c|c|c|c|c|c|c|c|}
\hline 2 & Core Activity & 4,0 & 4,0 & 3,0 & 4,0 & 3,0 & 3,6 \\
\hline 3 & Closing & 3 & 3 & 3 & 3 & 3 & 3,0 \\
\hline 4 & $\begin{array}{l}\text { Ability to } \\
\text { manage time }\end{array}$ & 3,6 & 3,4 & 3,6 & 3,8 & 3,4 & 3,5 \\
\hline 5 & Class situation & 3,0 & 3.0 & 3,0 & 3,0 & 3,0 & 3,0 \\
\hline
\end{tabular}

The summary of RPP analysis results can be explained as follows: a) Preliminary aspects include 1) The teacher conditions the class in an atmosphere conducive to ongoing learning; 2) The teacher provides illustrations to motivate students about the subject matter; 3) The teacher conveys the learning objectives to be achieved, including aspects assessed during the learning process; 4) The teacher does apperception by giving classical questions that lead by exploring the subject matter. The average value of the preliminary aspect is $X=3.7$. Thus, the preliminary aspects in the RPP are included in the category of "very valid" ( $3.5 \leq X \leq 4.0)$ and can be declared valid for use in disciplinarybased teaching of CRE according to the Gospel of Matthew 28: 19-20.

b) Aspects of core activities include 1) Ability to Present Phenomena. The teacher presents social phenomena about the subject matter that occurs within the wider community, the Bible from various sources, or media; 2) Observing Ability. Students who have been divided into groups led by peer tutors are given the task to learn various forms or factors about the subject matter contained in the community and the Bible. Besides, students led by peer tutors read several concepts about the subject matter from various sources of information or references that have been assigned to see and read; 3) Questioning Ability. Students led by peer tutors are motivated to answer questions about the subject matter. Encourage students to want to ask questions, issue opinions, or answer questions; 4) The ability to explore, explore subject matter, analyze subject matter; 5) Associate subject matter with certain fields such as character; 6) Ability to communicate. Students who are mentored by peer tutors present and present in various forms, both written and oral, about the subject matter; 7) The ability to guide from peer tutors to students (groups) to be able to work together; 8) Ability to facilitate the interaction of peer tutors, teachers, and students with students, 9) Ability to process classes. 10) Ability to appreciate various opinions, 11) Students respond positively to peer tutors and vice versa also respond positively to the participation of fellow students 12) Ability 
to demonstrate skills in the use of learning resources/learning media. The average value of core activities is $X=3.6$. Thus, the core activities are included in the "very valid" category $(3.5 \leq X \leq 4.0)$. Aspects of core activities can be stated to be very valid to be used in teaching CRE.

c) Concluding aspects include 1) The ability to reflect or make a summary by involving students and peer tutors. 2) The ability to carry out follow-up by giving direction, activities, or tasks as part of enrichment. The average closing aspect value is $X=3.0$. Thus, the core activities are included in the "valid" category $(3.0 \leq X \leq 3.49)$. The closing aspects of the lesson plan can be stated to be very valid for use in teaching CRE.

d) The aspect of the ability to manage time has an average value of $X=$ 3.5. Thus, the aspect of the ability to manage time is included in the category of "valid" $(3.0 \leq X \leq 3.49)$. Aspects of the ability to manage RPP time can be stated to be very valid to be used in CRE-based discipleship teaching according to the Gospel of Matthew 28: 19-20.

e) Aspects of the classroom atmosphere include 1) Enthusiastic students;

2) Enthusiastic peer tutors; 3) Enthusiastic teachers. The average value of aspects of the class atmosphere is $X=3.0$. Thus, the class atmosphere is included in the "valid" category $(3.0 \leq X \leq 3.49)$. So, aspects of the RPP classroom atmosphere can be stated to be very valid for use in CREbased discipleship teaching according to the Gospel of Matthew 28: 1920.

\section{Results of Analysis of Teacher Activity Activities of Peer Tutor Learning Models}

In observing the activities of the teacher's peer tutor learning model, a number of things were assessed: a) Preliminary aspects, b) Core activities, c) Closing, d) Ability to manage time, e) Classroom atmosphere. The results of the observer assessment are illustrated in table 4.

Table 4. Teacher Activity Peer Tutor Learning Model

\begin{tabular}{llllllll}
\hline \multirow{2}{*}{ Numb. } & \multirow{2}{*}{ Aspect } & \multicolumn{5}{c}{ Observer } & Average \\
\cline { 2 - 7 } & & 1 & 2 & 3 & 4 & 5 & \\
\hline 1 & Introduction & 3,6 & 3,8 & 4,0 & 3,6 & 3,6 & 3,7 \\
2 & Core Activity & 3,6 & 3,4 & 3,6 & 3,8 & 3,6 & 3,5 \\
3 & Closing & 3,4 & 3,6 & 3,4 & 3,2 & 3,4 & 3,4
\end{tabular}




\begin{tabular}{|c|c|c|c|c|c|c|c|}
\hline 4 & $\begin{array}{l}\text { Ability to manage } \\
\text { time }\end{array}$ & 3,6 & 3,4 & 3,6 & 3,8 & 3,4 & 3,5 \\
\hline 5 & Class situation & 3,0 & 3.0 & 3,0 & 3,0 & 3,0 & 3,0 \\
\hline
\end{tabular}

The summary of the results of the observer's evaluation of the activities of the teacher's peer tutor learning model can be explained as follows:

a) Preliminary aspects include: 1) The teacher conditions the class in an atmosphere conducive to ongoing learning. 2) The teacher coordinates with the peer tutors who have been selected and trained. 3) Teachers give assignments to peer tutors to become leaders/guide their friends (students). 4) The teacher conveys the learning objectives to be achieved, including aspects that are assessed during the learning process. 5) The teacher does apperception by giving classical questions that are guided by exploring the subject matter. The average value of the preliminary aspects of the teaching activities of the peer tutoring learning model is $X=3.7$. Thus, included in the category of "very valid" $(3.5 \leq X \leq 4.0)$. The preliminary aspects of the teaching activities of the peer tutoring learning model are stated to be very valid to be used in CRE-based discipleship teaching according to the Gospel of Matthew 28: 19-20.

b) Aspects of core activities include 1) Ability to Present Phenomena. The teacher presents social phenomena about the subject matter that occurs within the wider community, the Bible, videos from various sources or media. 2) Observing Ability. The teacher gives assignments to students who are led/guided to learn various forms or factors about the subject matter contained in the community and the Bible. The teacher assigns students led by peer tutors to view videos, read stories, the Bible about the subject matter from various sources of information or references. 3) Questioning Ability. The teacher gives questions related to the subject matter. The teacher encourages students to ask questions, issue opinions, or answer questions. 4) Exploration Ability. The teacher gives opportunities to students who are guided by peer tutors to: Explore subject matter, Analyze subject matter. 5) Associate. The teacher gives opportunities to students who are taught by peer tutors to associate subject matter with certain fields such as character. 6) The ability to communicate. The teacher motivates students who are mentored by peer tutors to present and present in various forms, both 
written and oral, about the subject matter. 7) The teacher motivates and facilitates peer tutors and students to work together. 8) Ability to process classes. The teacher arranges the class. 9) The ability to appreciate various opinions. The teacher appreciates the work of peer tutors and students. The average value of aspects of the core activities of teachers of peer tutor learning models is $X=3.5$. Thus, included in the category of "very valid" $(3.5 \leq X \leq 4.0)$. So, aspects of the core activities of the teacher's peer tutor learning model are stated to be very valid in the teaching of disciplinary-based CRE according to the Gospel of Matthew 28: 19-20.

c) Concluding aspects include: 1) The teacher reflects or makes a summary by involving students and peer tutors. 2) The teacher carries out follow-up by giving directions, activities, or assignments as part of the enrichment. The average value of the closing aspects of the teaching activities of the peer tutoring learning model is $X=3.4$. Thus, included in the category of "valid" $(3.0 \leq X \leq 3.49)$. So, aspects of the closing activities of the tutor peer learning model are declared valid in the teaching of disciplinary-based CRE according to the Gospel of Matthew 28: 19-20.

d) Aspects of the ability to manage time include: 1) The ability of teachers to manage the class. 2) The accuracy of the teacher in using time. The average value of the teacher's time management aspects of the peer tutoring learning model is $X=3.5$. Thus, included in the category of "very valid" ( $3.5 \leq X \leq 4.0)$. Aspects of the teacher's time management model of peer tutoring learning are stated to be very valid in teaching CRE-based discipleship according to the Gospel of Matthew 28: 19-20.

e) The class atmosphere includes 1) Students and peer tutors are enthusiastic about following the teaching and learning process; 2) Teachers are creative, innovative, and fun in the PBM process. The average value of the classroom atmosphere aspects of the peer tutor learning model is $\mathrm{X}=3.0$. Thus, included in the category of "valid" $(3.0 \leq$ $X \leq 3.49$ ). So, the classroom atmosphere aspect of peer tutoring learning models is declared valid in the teaching of disciplinary-based CRE according to the Gospel of Matthew 28: 19-20.

\section{Analysis of Teacher and Student Activities}

Results of Analysis of Teacher Activity 
In observing the teacher's activities, the observer assesses several things, namely: aspects of instructions, issues of language, and aspects of content. The results of the observer assessment are illustrated in table 5. Table 5. Teacher's Activities

\begin{tabular}{|c|c|c|c|c|c|c|c|}
\hline \multirow{2}{*}{ Numb. } & \multirow{2}{*}{ Aspect } & \multicolumn{5}{|c|}{ Observer } & \multirow[t]{2}{*}{ Average } \\
\hline & & 1 & 2 & 3 & 4 & 5 & \\
\hline 1 & Guide & 3,6 & 3,4 & 3,6 & 3,8 & 3,6 & 3,5 \\
\hline 2 & Language & 3,4 & 3,6 & 3,4 & 3,2 & 3,4 & 3,4 \\
\hline 3 & Content & 3,6 & 3,4 & 3,6 & 3,8 & 3,4 & 3,5 \\
\hline
\end{tabular}

The summary of the observer's assessment of the teacher's activities can be explained as follows:

a) Aspects of instructions include: 1) Instructions on teacher activity sheets using learning methods are written. 2) Teacher observation sheet activities using methods that are easy to implement. 3) The criteria for teacher activities are clearly stated. The average value of the instructional aspect of teacher activities is $X=3.5$. Thus, included in the category of "very valid" ( $3.5 \leq X \leq 4.0)$. The teacher's instructional aspect of peer tutoring learning models is declared valid in disciplinary-based teaching of CRE according to the Gospel of Matthew 28: 19-20.

b) Aspects of language include: 1) The use of the language used in the Indonesian language is good and right. 2) Clarity of instructions for solving the problem. 3) The simplicity of sentence structure. 4) The language used is communicative. The average value of aspects of the teacher's language is $X=3.4$. Thus, included in the category of "valid" (3.0 $\leq X \leq 3.49$ ). The aspect of teacher language in the peer tutoring learning model is stated to be valid in CRE-based discipleship teaching according to the Gospel of Matthew 28: 19-20.

c) Content aspects include: 1) The purpose of using teacher observation sheets is clearly and measurably formulated. 2) Overlooked aspects include the indicators of teacher stages in using the peer tutoring model. 3) Every assessment of the observation sheet uses words/statements that demand the giving of grades. The average value of the teacher content aspect is $X=3.5$. Thus, included in the category of "very valid" $(3.5 \leq X \leq$ 4.0). The aspect of teacher content in the peer tutoring learning model is stated to be very valid in the teaching of disciplinary-based CRE according to the Gospel of Matthew 28: 19-20. 
Results of Analysis of Student Tutor Activities

In observing the activities of the tutor, the observer assesses several things, namely: preliminary aspects, core activities, and closing. The results of the observer assessment are illustrated in table 6 .

Table 6. Tutor Student Activities

\begin{tabular}{|c|c|c|c|c|c|c|c|}
\hline \multirow[t]{2}{*}{ Numb } & \multirow{2}{*}{ Aspect } & \multicolumn{5}{|c|}{ Observer } & \multirow[t]{2}{*}{ Average } \\
\hline & & l & 2 & 3 & 4 & 5 & \\
\hline 1 & Introduction & 3,6 & 3,4 & 3,6 & 3,8 & 3,4 & 3,5 \\
\hline 2 & Core Activity & 3,5 & 3,5 & 3,5 & 3,4 & 3,6 & 3,5 \\
\hline 3 & Closing & 3,4 & 3,6 & 3,4 & 3,2 & 3,4 & 3,4 \\
\hline
\end{tabular}

The summary of the observer's assessment of tutor-student activities can be explained as follows:

a) Preliminary aspects include: 1) Peer tutors are enthusiastic about hearing teacher guidance. 2) Peer tutors listen to illustrations and motivate other students to listen. 3) Peer tutors take notes and listen to the learning objectives to be achieved, including aspects that are assessed during the learning process. 4) Peer tutors guide students to answer questions given by the teacher. The average value of the first aspects of tutor students is $X=3.5$. Thus, included in the category of "very valid" ( $3.5 \leq X \leq 4.0)$. The preliminary aspects of the student tutors' peer learning model expressed very valid in teaching CRE-based discipleship according to the Gospel of Matthew 28: 19-20.

b) Aspects of core activities include: 1) Observing ability. Peer tutors guide students to observe and learn various forms or factors about the subject matter contained in society and the Bible. Peer tutors divide assignments to students in the group to read some concepts about the subject matter from various sources of information or references that have been assigned to see and read. 2) Questioning Ability. Peer tutors motivate students to ask questions about the subject matter. Peer tutors want to ask questions and express opinions. 3) Exploration Ability. Peer tutors give examples of exploring subject matter to students. Peer tutors Analyze subject matter. Peer tutors provide examples of positive character for students. 4) Associate. Peer tutors classify positive characters of Christ disciples according to the subject matter. 5) The ability to communicate. Peer tutors guide students to do the truth in accordance with the subject matter. 6) The ability to appreciate various 
opinions. Peer tutors value the opinions of group members; students respond positively to the opinions of peer tutors and the opinions of fellow students. 7) Peer tutors guide students to use learning resources/ learning media. The average value of aspects of the tutor student's core activities is $X=3.5$. Thus, included in the category of "very valid" $(3.5 \leq X$ $\leq 4.0$ ). Aspects of the core activities of student tutors peer tutoring learning models are stated to be very valid in teaching CRE based discipleship according to the Gospel of Matthew 28: 19-20.

c) Concluding aspects include: 1) Peer tutors guide students to reflect or make a summary of the subject matter. 2) Peer tutors guide students to create works/products following the subject matter. The average value of the closing student tutoring activity aspect is $X=3.4$. Thus, included in the category of "valid" $(3.0 \leq X \leq 3.49)$. Aspects of the core activities of student tutors peer learning models are declared valid in the teaching of disciplinary-based CRE according to the Gospel of Matthew 28: 19-20.

Results of Analysis of Student Activities

In observing student activities, the observer assesses several things, namely: preliminary aspects, core activities, and closing. The results of the observer assessment are illustrated in table 7.

Table 7. Student Activities

\begin{tabular}{llllllll}
\hline \multirow{2}{*}{ Numb } & \multirow{2}{*}{ Aspect } & \multicolumn{5}{c}{ Observer } & \multirow{2}{*}{ Average } \\
\cline { 3 - 6 }. & & 1 & 2 & 3 & 4 & 5 & \\
\hline 1 & Introduction & 3,6 & 3,4 & 3,4 & 3,2 & 3,4 & 3,4 \\
2 & Core Activity & 3,5 & 3,5 & 3,5 & 3,4 & 3,6 & 3,5 \\
3 & Closing & 3,6 & 3,4 & 3,6 & 3,8 & 3,4 & 3,5 \\
\hline
\end{tabular}

The summary of the observer's assessment of student activities can be explained as follows:

a) Preliminary aspects include: 1) Students prepare to learn tools. 2) Students enthusiastically listen to the illustrations provided by the teacher. 3) Students take notes and listen to the learning objectives to be achieved, including aspects assessed during the learning process. 4) Students answer the questions given by the teacher. The average value of aspects of core student activities is $X=3.4$. Thus, included in the category of "valid" $(3.0 \leq X \leq 3.49)$. Aspects of the core activities of students of peer tutoring learning models are declared valid in the 
teaching of disciplinary-based CRE according to the Gospel of Matthew 28: 19-20.

b) Aspects of core activities include: 1) Observing ability. Students enthusiastically observe and learn various forms or factors about the subject matter found in society and the Bible. Students enthusiastically read several concepts about the subject matter from various sources of information or references that have been assigned to see and read. 2) Questioning Ability. Students answer questions about the subject matter. Students want to ask questions and issue opinions. 3) Exploration Ability. Students Explore subject matter. Students Analyze subject matter. 4) Associate. Students associated with the subject matter that is connected with the character. 5) The ability to communicate. Students present and present in various forms, both written and oral, about the subject matter. 6) The ability to appreciate various opinions. Students respond positively to the opinions of peer tutors and the opinions of fellow students. 7) Students are able to use learning resources / learning media. The average value of aspects of core student activities is $X=3.5$. Thus, included in the category of "very valid" $(3.5 \leq X$ $\leq 4.0$ ). Aspects of the core activities of students of peer tutoring learning models are stated to be very valid in teaching CRE-based discipleship according to the Gospel of Matthew 28: 19-20.

c) The closing aspects include: 1) Students reflect or make a summary of the subject matter. 2) Students make the work/product following the subject matter. The average value of aspects of student closing activities is $X=3.5$. Thus, included in the category of "very valid" $(3.5 \leq X \leq 4.0)$. The closing aspect aspects of student activities of peer tutor learning models are stated to be very valid in teaching CRE based discipleship according to the Gospel of Matthew 28: 19-20.

From all the tests carried out from the initial stages until the revised design tests, it was proven that the CRE learning component based on discipleship according to Matthew 28: 19-20 by using a peer tutoring learning model is valid and valid for use in high school. The enthusiasm of students and tutors in participating in CRE-based discipleship teaching according to the Gospel of Matthew 28: 19-20 can have an impact on a better understanding of the material being taught, and the purpose of the Great Commission can be implemented. 


\section{Conclusion}

Based on data analysis in this study, it can be concluded based on the following problem formulation. First, the teacher handbook that was published based on material provided by the Ministry of Education of the Republic of Indonesia was not in line with the concept of discipleship of the Great Commission, according to the Gospel of Matthew 28: 19-20. Second, valid and valid peer tutoring learning models are used in teaching CRE in high school. Third, Disciplinary CRE Teaching Implementation Plan, according to the Gospel of Matthew 28: 19-20, is valid and valid for use in high schools. Fourth, CRE-based teaching of discipleship, according to the Gospel of Matthew 28: 19-20, is in line with the Great Commission, thus increasing the chances of the commission being carried out.

\section{Bibliography}

Borg, W. R., and M. D. Gall. Educational Research: An Introduction. New York: Longman, 1983.

Clark, Robert E., Lin Johnson, and Allyn K. Sloat. Christian Education: Foundations for the Future. Moody Publishers, 1991.

Cox, William, and Robert Peck. "Christian Education as Discipleship Formation." Christian Education Journal: Research on Educational Ministry 15 (June 7, 2018): 073989131877885. https://doi.org/10.1177/0739891318778859.

Gordon, Edward E. Peer Tutoring: A Teacher's Resource Guide. R\&L Education, 2005.

Herwinesastra, Herwinesastra. "Pengaruh Model Mentoring Robert Clinton Terhadap Kecakapan Kepemimpinan Pekerja di GKII Daerah Pontianak." Jurnal Jaffray 17, no. 2 (October 11, 2019): 259-79. https://doi.org/10.25278/jj.vl7i2.365.

Hull, Bill. The Complete Book of Discipleship: On Being and Making Followers of Christ. Colorado Springs: NavPress, 2014.

Maiaweng, Peniel C. D. "Ulasan Buku: Spiritual Formation: Menjadi Serupa dengan Kristus." Jurnal Jaffray 13, no. 1 (March 28, 2015): 141-43. https://doi.org/10.25278/jj7l.vl3il.119.

Muthma'innah, M. "What's about Peer Tutoring Learning Model?" Journal of Physics: Conference Series 895 (September 2017): 012064. https://doi.org/10.1088/1742-6596/895/1/012064.

Nuhamara, Daniel. "Pengutamaan Dimensi Karakter Dalam Pendidikan Agama Kristen." Jurnal Jaffray 16, no. 1 (March 19, 2018): 93. https://doi.org/10.25278/jj7l.vl6il.278. 
Prihanto, Agus. "Peran Proses Mentoring Pemimpin Kaum Muda Bagi Perkembangan Pelayanan Pemuda Di Gereja." Jurnal Jaffray 16, no. 2 (October 6, 2018): 197-212. https://doi.org/10.25278/jj71.vl6i2.258.

Roberts, Carlos C. Christian Education Teaching Methods - from Modern to Postmodern: Teaching the Faith to Post-Moderns. Bloomington: AuthorHouse, 2009. Sidjabat, Binsen Samuel. "Kerangka Kurikulum Pendidikan Agama Kristen Berbasis Karakter di Perguruan Tinggi." Jurnal Jaffray 17, no. 1 (April 5, 2019): 73. https://doi.org/10.25278/jj7l.vl7il.314.

Tye, Karen. Basics of Christian Education. Chalice Press, 2000.

Villa, Richard A., Jacqueline S. Thousand, and Ann I. Nevin. Collaborating With Students in Instruction and Decision Making: The Untapped Resource. Corwin Press, 2010.

Wijaya, Hengki, and Arismunandar Arismunandar. "Pengembangan Model Pembelajaran Kooperatif Tipe STAD Berbasis Media Sosial." Jurnal Jaffray 16, no. 2 (October 6, 2018): 175-96. https://doi.org/10.25278/jj7l.vl6i2.302. 